NEW TECHNIQUES OF OPTICAL MICROSCOPY AND MICROSPECTROSCOPY 


\section{TOPICS IN MOLECULAR AND STRUCTURAL BIOLOGY}

Stephen Neidle

Institute of Cancer Research

Sutton, Surrey, UK
Series Editors

\author{
Watson Fuller \\ Department of Physics \\ University of Keele, UK
}

Volume 9 Topics in Nucleic Acid Structure, Part 3

Edited by Stephen Neidle (1987)

Volume 10 Protein-Nucleic Acid Interaction Edited by Wolfram Saenger and Udo Heinemann (1989)

Volume 11 Calcified Tissue

Edited by David W. L. Hukins (1989)

Volume 12 Oligodeoxynucleotides

Edited by Jack S. Cohen

Volume 13 Molecular Mechanisms in Muscular Contraction Edited by John M. Squire

Volume 14 Connective Tissue Matrix, Part 2

Edited by David W. L. Hukins

Volume 15 New Techniques of Optical Microscopy and Microspectroscopy Edited by Richard J. Cherry 
Topics in Molecular and Structural Biology

Volume 15

\title{
NEW TECHNIQUES OF \\ OPTICAL MICROSCOPY \\ AND \\ MICROSPECTROSCOPY
}

\author{
Edited by \\ RICHARD J. CHERRY \\ Dept of Chemistry and Biological Chemistry \\ University of Essex \\ Colchester, England
}

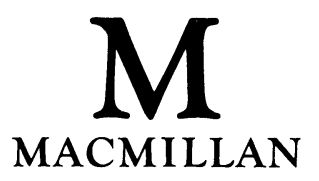


(C) The Macmillan Press Ltd 1991

Softcover reprint of the hardcover 1st edition 1991 978-0-333-49108-9

All rights reserved. No reproduction, copy or transmission of this publication may be made without written permission.

No paragraph of this publication may be reproduced, copied or transmitted save with written permission or in accordance with the provisions of the Copyright, Designs and Patents Act 1988, or under the terms of any licence permitting limited copying issued by the Copyright Licensing Agency, 33-4 Alfred Place, London WC1E 7DP.

Any person who does any unauthorized act in relation to this publication may be liable to criminal prosecution and civil claims for damages.

First published 1991

Published by

THE MACMILLAN PRESS LTD

Houndmills, Basingstoke, Hampshire RG21 2XS

and London

Companies and representatives

throughout the world

Typeset by Latimer Trend \& Company Ltd

Plymouth

British Library Cataloguing in Publication Data

New techniques of optical microscopy and microspectroscopy.

1. Optical microscopy

I. Cherry, Richard J.

502.82

ISSN 0265-4377

ISBN 978-1-349-10804-6 ISBN 978-1-349-10802-2 (eBook)

DOI 10.1007/978-1-349-10802-2 


\section{Contents}

Preface $\quad$ ix

The Contributors $\quad \mathrm{xi}$

1 Video and opto-digital imaging microscopy Introduction $\quad 1$

Video enhanced contrast microscopy $\quad 5$

$\begin{array}{ll}\text { Intensified fluorescence microscopy } & 21\end{array}$

Computational deblurring of fluorescence images 28

$\begin{array}{ll}\text { Three-dimensional cellular tomography } & 40\end{array}$

2 The confluence of advances in light microscopy: CCD, confocal, near-field and molecular exciton microscopy

A. Lewis $\quad 49$

Introduction $\quad 49$

Optical microscopy with a lens $\quad 50$

$\begin{array}{ll}\text { Optical microscopy without lenses } & 71\end{array}$

$\begin{array}{ll}\text { Summary } & 87\end{array}$

3 Quantitative interference microscopy

G. A. Dunn $\quad 91$

Introduction $\quad 91$

$\begin{array}{ll}\text { Optical interference and interferometers } & 93\end{array}$

Interference reflection microscopy $\quad 97$

$\begin{array}{lr}\text { Transmission interferometric microscopy } & 107\end{array}$

$\begin{array}{ll}\text { Summary } & 115\end{array}$

4 The dynamic study of cell surface organization by nanoparticle video microscopy

H. Geerts, M. De Brabander, R. Nuydens and R. Nuyens 119

Introduction $\quad 119$ 
Technical aspects of nanovid microscopy $\quad 120$

$\begin{array}{ll}\text { Quantitative measurements } & 122\end{array}$

Dynamics of cell surface organization $\quad 123$

$\begin{array}{ll}\text { Discussion } & 132\end{array}$

5 Microscope laser light scattering spectroscopy

J. A. Peetermans, I. Nishio and T. Tanaka

Introduction: quasi-elastic laser light scattering (QLS) and

microscope laser light scattering spectroscopy (MLLSS)

MLLSS

A few MLLSS studies

Conclusion: an elegant method with room for improvement

6 Differential polarization microscopy

W. E. Nickols

Introduction

Historical perspective: An overview of the microspectrophotometry of linear dichroisal, circular dichroisal and differential scattering

Theoretical description of light interacting with matter

Results from imaging and solution work

Experimental measures of differential polarization effects 164

Conclusion

7 Time-resolved fluorescence microscopy

R. Tian and M. A. J. Rodgers

Introduction

Instrumentation

Data acquisition and analysis $\quad 186$

Applications

Concluding remarks

8 Fluorescence photobleaching techniques

R. Peters and M. Scholz

Introduction

Basic concepts

Instrumentation

Radiation-induced artefacts

Conclusion and perspective

9 Measuring cytoplasmic calcium in single living cells using fluorescent probes 
Principles of single-cell measurement $\quad 230$

Instrumentation and techniques $\quad 232$

Fura-2 compared with Indo-1 241

Problems $\quad 242$

Imaging $\quad 245$

Comparison of fluorescence and other optical techniques 247

Measuring $\left[\mathrm{Ca}^{2+}\right]_{\mathrm{i}}$ in conjunction with other techniques 248

$\begin{array}{ll}\text { Measuring other ions by fluorescence } & 249\end{array}$

10 Membrane potential imaging

L. M. Loew $\quad 255$

Introduction $\quad 255$

Multisite mapping of membrane potential with potentiometric

$\begin{array}{ll}\text { dyes } & 257\end{array}$

A fast potentiometric indicator detects variations in membrane $\begin{array}{ll}\text { potential along the surface of single cells } & 259\end{array}$

Slow redistribution dyes can simultaneously follow membrane potential across the plasma and mitochondrial membranes 263

$\begin{array}{ll}\text { Conclusion } & 269\end{array}$

Index

273 


\section{Preface}

Although the use of optical microscopy in biology has a long history, the last few years have seen a dramatic renewal of interest in its application. A whole new range of methodologies have been, or are being, developed, which add greatly to the power and scope of microscopy using visible light. The aim of this book is to provide an up-to-date account of the major developments.

The recent advances in optical microscopy subdivide into a number of interlocking areas. The early chapters of the book focus on developments which dramatically improve the quality of the image. Such methods have greatly benefited from the explosive growth of readily available computational power which has taken place over the past decade. In conjunction with scanning technologies, remarkable two-dimensional images and threedimensional reconstructions are now obtainable with new standards of resolution and contrast. New lensless techniques of optical imaging are being devized which take spatial resolution beyond the fundamental physical limits imposed by lens-based systems.

In part associated with these improvements in image quality are methods for quantitatively investigating dynamic events in cells. An important advantage of optical microscopy over electron microscopy is that measurements can be made on living cells, thus permitting dynamic events to be observed. Techniques have been developed based on video-enhanced contrast microscopy which enable direct observation of the movements of cellular structures or of colloidal metal particles attached to specific molecules. Further methods for measuring molecular motion are based on fluorescence and quasi elastic light scattering. Interferometric microscopy in conjunction with image processing is particularly suitable for analysing cell growth and mobility.

Fluorescence is a versatile spectroscopic technique which has been employed in innumerable ways to study biological molecules in macroscopic samples. The high sensitivity of fluorescence has of course also long been 
exploited in microscopy. However, in addition to visualization, new methodologies permit extension of fluorescence spectroscopic techniques, such as time-resolved fluorescence and monitoring of membrane potentials, to the single cell level. The development of fluorescence indicators for visualizing and measuring specific ion concentrations in cells is also finding widespread application.

It is apparent that modern optical microscopy is an interdisciplinary activity involving the combined efforts of biologists, biochemists, chemists, computer programmers and physicists. I hope that this book will succeed in conveying something of the excitement of current work in this area and encourage others to become involved in the further development of new techniques and their applications.

Colchester, 1990

R. J.C. 


\section{The Contributors}

Christopher D. Benham

Smith, Kline \& French Research Ltd

The Frythe

Welwyn

Herts AL6 9AR

England

Mark De Brabander

Dept of Life Sciences

Janssen Research Foundation

B-2340 Beerse

Belgium

Graham A. Dunn

MRC Cell Biophysics Unit

King's College

26-29 Drury Lane

London WC2B 5RL

England

\section{Hugo Geerts}

Dept of Life Sciences

Janssen Research Foundation

B-2340 Beerse

Belgium
Ron Jacob

Smith, Kline \& French Research

Ltd

The Frythe

Welwyn

Herts AL6 9AR

England

Aaron Lewis

The Hebrew University of Jerusalem

Jerusalem

Israel

Leslie M. Loew

Dept of Physiology

University of Connecticut Health Center

263 Farmington Ave

Farmington

CT 06032

USA

\section{William Mickols}

Dow Chemical Co.

Western Applied Science and

Technology Laboratories

PO Box 9002

Walnut Creek

CA 94598-0902

USA 
Izumi Nishio

Dept of Physics

Aoyamagakuen University

Setagayaku

Tokyo

Japan

Rony Nuydens

Dept of Life Sciences

Janssen Research Foundation

B-2340 Beerse

Belgium

\section{Roger Nuyens}

Dept of Life Sciences

Janssen Research Foundation

B-2340 Beerse

Belgium

Joyce A. Peetermans

Oculon

26 Landsdowne St

Cambridge

MA 02139

USA

\section{Reiner Peters}

Max-Planck-Institut für Biophysik

Heinrich-Hoffmann-Str. 7

D-6000 Frankfurt 71

FR Germany
Michael A. J. Rodgers

Center for Photochemical Sciences

Dept of Chemistry

Bowling Green State University

Bowling Green

OH 43403

USA

\section{Manfred Scholz}

Max-Planck-Institut für Biophysik

Heinrich-Hoffmann-Str. 7

D-6000 Frankfurt 71

FR Germany

David M. Shotton

Dept of Zoology

University of Oxford

South Parks Rd

Oxford OX1 3PS

England

\section{Toyoichi Tanaka}

Dept of Physics and Center for Material Science and Engineering

Massachusetts Institute of Technology

Cambridge

MA 02139

USA

\section{Rujiang Tian}

Center for Photochemical Sciences

Dept of Chemistry

Bowling Green State University

Bowling Green

OH 43403

USA 